\title{
Effects of Grazing Alone as Against Three Schedules of Supplementation from Breeding Age to First Parturition in Holstein Heifers ${ }^{1}$
}

\author{
P. F. Randel and J. Vélez-Santiago ${ }^{2}$
}

\begin{abstract}
Sixty Holstein heifers supplied by private farms were stratified by liveweight into 15 quartets upon reaching breeding age, and used in a randomized block design with four treatments, based on grazing with or without supplementation, until shortly after parturition. Treatments were: 1) stocking rate of 3.125 animals/ha, fertilization with $2.25 \mathrm{t} /$ ha of a 15-5-10 analysis annually, without supplemental feeding; 2) same stocking rate, 1.65 t of fertilizer, supplementation with $3 \mathrm{~kg}$ per head daily of bulky concentrates, beginning at 3 months pregnant; 3) 5 animals/ha, fertilization with $2.25 \mathrm{t} / \mathrm{ha}$, $1.8 \mathrm{~kg}$ daily of conventional concentrates continuously; 4 ) as in treatment 3 , except for supplementation at $4 \mathrm{~kg}$ daily from the 5 th month of pregnancy onward.

In 270 days mean liveweights increased from $347 \mathrm{~kg}$ initially to values ranging from $502 \mathrm{~kg}$ to $517 \mathrm{~kg}$ for treatments 4 and 1, respectively. Daily gains of .63, .57, .61, and $.58 \mathrm{~kg}$ in the four respective treatments were not significantly different. Treatments affected growth in body dimensions minimally. Mean age at first calving ranged from 30.8 to 32.2 months for treatments 4 and 2, respectively. Mean first lactation milk yields (305-day mature-equivalent DHIA records) by heifers formerly in the four respective treatments were 4,210 , $4,253,4,762$, and $4,683 \mathrm{~kg}$, not differing significantly. Under excellent grazing conditions, as in this experiment, concentrate feeding prepartum was not shown to be necessary for satisfactory growth, reproduction and milk yield, but it did result in a lower postpartum attrition rate than grazing only during rearing.
\end{abstract}

\section{INTRODUCTION}

The international scientific literature contains few references to studies on the rearing of dairy replacement heifers on tropical pastures. According to one report from Cuba, pangolagrass (Digitaria decumbens) swards, fertilized with $120-150 \mathrm{~kg} \mathrm{~N} / \mathrm{ha}$ annually and stocked with 5 heifers/ha promotes adequate growth during the rainy season, but $1 \mathrm{~kg}$ per head daily of supplemental concentrates is recommended during the dry season. Under these conditions animals typically reach a suitable breeding stage of $320 \mathrm{~kg}$ at 14 months of age (1).

In a series of local studies, intensively managed grass pastures with suitable stocking rates have supported daily gains in Holstein heifers of .5 to $.6 \mathrm{~kg}$ per head over extended periods of time $(2,4,5,6,8)$. Supplemental feeding of additional energy and protein sources has enhanced growth only slightly and has not proven to be economical $(2,5$,

${ }^{1}$ Manuscript submitted to Editorial Board September 14, 1982.

${ }^{2}$ Nutritionist, Lajas Agricultural Research and Development Center, and Associate Agronomist, Corozal Substation, Agricultural Experiment Station, University of Puerto Rico, Mayagüez Campus. The authors express their appreciation to Eugenio Marrero for his assistance in this work. 
6). However, the heifers used in these experiments were not evaluated later as to the effects of experimental treatments on subsequent milk production. Casual observation suggested that heifers reared on grazing only might be more likely to become poor milk producers or to have other problems leading to their early elimination from the herd.

The present experiment was undertaken to evaluate four treatments, differing in stocking rate in pasture, level of fertilization and program of supplemental feeding on the growth of Holstein heifers from breeding age to first calving and to investigate carry-over effects of rearing treatments on post-partum performance.

\section{MATERIALS AND METHODS}

Seventy-eight 8-to-9-month-old Holstein heifers, belonging to private herds $^{3}$, were transported to the Corozal Substation in June 1977. They were first used in an experiment in which three different treatments, consisting of grazing plus supplemental concentrates, were compared. This study was finalized June 1, 1978, at which time most of the heifers had reached a suitable breeding size of at least $340 \mathrm{~kg}$. Sixty of the same animals were selected to immediately begin the present experiment. These were stratified by liveweight into 15 quartets, and one animal from each was assigned at random to each of four treatment groups.

Treatments differed in three factors: stocking rate in pasture, amount of fertilizer applied to pastures, and program of feeding supplemental concentrates. Stocking rate was 3.125 animals/ha in treatments 1 and 2 vs. $5 /$ ha in treatments 3 and 4 . Fertilization rate (15-5-10 analysis) was $2.25 \mathrm{t} / \mathrm{ha}$ in treatments 1,3 , and $4 \mathrm{vs} .1 .65 \mathrm{t} / \mathrm{ha}$ in treatment 2. Supplemental feeding differed in all four treatments as follows: 1) no supplementation; 2) $3 \mathrm{~kg}$ per head daily of a $14 \%$ crude protein (CP) bulky concentrate mixture beginning at 3 months pregnant and thereafter for the duration of the experiment; 3) $1.8 \mathrm{~kg}$ daily of a $14 \% \mathrm{CP}$ conventional concentrate continuously; and 4) $4 \mathrm{~kg}$ daily of the latter supplement from the 5th month of gestation onward.

The swards were of mixed gramineous composition. Principal botanical species present, in decreasing order of importance, were carib (Eriochloa polystachya), parà (Brachiaria purpurascens), guinea (Panicum maximum), and pangola grasses. Fertilizer was applied in the indicated amount at a 3-month interval, and lime was added to the soil when necessary. Groups 1 and 2 each rotated among four different paddocks (three of 1.3 ha and one of .9 ha), while groups 3 and 4 each rotated among three of .8 ha and one of .6 ha. Intervals between successive grazings of a given paddock were 21 to 24 days. No artificial shade and

\footnotetext{
${ }^{3}$ Cooperation of the Fonalledas family is gratefully acknowledged.
} 
little natural shade was available in the pastures. All groups had continuous access to water and trace mineralized salt. The concentrate supplements were fed in covered feed bunks located in an enclosed and divided area.

The animals were weighed on 11 occasions after a night in confinement without feed or water. After initial weighing, reweighing was at 4-week periods, except for a 16-day final period. Wither height, length from withers to pinbones and heart girth were also measured at weighings 1 , $2,3,4,7$, and 11 .

Insemination was by natural service at the first estrus observed after the heifer reached eligible breeding weight of $340 \mathrm{~kg}$. Heifers not conceiving were rebred as needed until pregnancy was confirmed by rectal palpation. After 24 weeks of experimentation, one heifer in treatment 2 was diagnosed sterile and replaced by another of similar weight belonging to the Experiment Station.

Calvings were due to begin in early March, 1979; thus the experiment was terminated on 26 February, to allow near-term heifers to be safely returned to their owners' farms before parturition. The 59 privately owned animals were distributed among four farms, two located in the northern coastal plain (Santa Elena and Candelaria) and two in the central hill country (Fortuna and Cidra). At each farm the returning heifers were divided among the former controls and those formerly of treatments 2,3 , and 4 . The latter received $2.3 \mathrm{~kg}$ per head daily of a $12 \%$ CP bulky concentrate until calving, while the controls continued without supplementation. All grazed improved pastures at a stocking rate of approximately 2.5 animals/ha.

After calving, all heifers at each farm were treated alike. Certain details varied among farms, but generally fertilized stargrass pastures were grazed at the above-mentioned stocking rate, and during early lactation, $9 \mathrm{~kg}$ per head daily of either a conventional concentrate or a combination of this plus bulky concentrate was fed; allowances were later reduced as production declined. Free access to salt was provided at all farms and in one case to a complete mineral mix also. The farms were visited periodically by the authors to follow the progress of returned animals. Milk. production was obtained from DHIA records. Animals were weighed on scales at Santa Elena; tape measure estimates of bodyweight were taken at the other three farms. Additional observations on health and reproduction were recorded by the herdsman at each farm.

Data from the experiment at Corozal were submitted to analysis of variance for a randomized blocks design, blocks referring to the 15 quartets of animals based on initial liveweight. Data from the follow up phase at the home farms were subjected to analysis of variance including 
the two factors, former treatment and farm treatment and their interaction.

\section{RESULTS AND DISCUSSION}

The following observations relative to liveweight gains during the first four 4-week periods are pertinent: during this interval only heifers of treatment 3 were receiving supplemental concentrates, while those of the other three treatments depended upon grazing alone; the former showed a daily gain of $.51 \mathrm{~kg}$ and the latter a combined mean of $.47 \mathrm{~kg}$. Heifers of treatments 1 and 2 grazed at 3.125 animals/ha, but with a lower rate of fertilization for the latter; corresponding daily means were $.57 \mathrm{~kg}$ and $.46 \mathrm{~kg}$. By contrast, treatment- 4 heifers, grazing at 5 animals $/$ ha, showed a lower mean of $.38 \mathrm{~kg}$ per day. Thus, the logical tendencies of lower stocking rate, higher level of fertilization and supplemental feeding to improve growth rates were apparent.

Individual animals of treatments 2 and 4 began receiving supplemental concentrates on different dates, the earliest being in periods 5 and 7 , respectively, while treatment-3 heifers continued with supplementation throughout the experiment. Mean quantities of concentrates consumed per animal, ranging from $275 \mathrm{~kg}$ to $486 \mathrm{~kg}$ among the three treatments involving supplementation (table 1), failed to produce any advantage over the controls of treatment 1 , or even to equal the latter in mean rate of gain (table 1). Corresponding daily means for the whole experiment were $.63 \mathrm{~kg}$ vs. $.59 \mathrm{~kg}$, a composite mean for treatments 2,3 and 4 . Grazing alone at the lower stocking rate and higher fertilization rate supported mean daily gains in control heifers ranging from $.29 \mathrm{~kg}$ in period 2 to $.88 \mathrm{~kg}$ in period 5 . Little seasonal variation from June to February was evident. Monthly rainfall was minimal (43 mm) in July, maximal $(167 \mathrm{~mm})$ in September and generally adequate for rapid herbage growth throughout the experiment. Ambient temperature showed mean monthly maxima varying from $31.7^{\circ} \mathrm{C}$ in August and September to $27.4^{\circ} \mathrm{C}$ in January and minima from $21.5^{\circ} \mathrm{C}$ in July and August to $17.9^{\circ} \mathrm{C}$ in January.

Treatment-3 heifers, receiving continuous supplementation, also showed little consistent seasonal trend in gain. Minimal daily increment of this group $(.13 \mathrm{~kg})$ occurred during the abbreviated 10th period, next lowest $(.29 \mathrm{~kg})$ in period 1 , and highest $(1.03 \mathrm{~kg})$ in period 6. These monthly means were more variable than those of the control, but withingroup variability was alike for both treatments over-all (standard errors in table 1). Combined data from all four groups showed lowest mean daily gain in period $4(.40 \mathrm{~kg})$ and highest in period $5(.78 \mathrm{~kg})$, both corresponding to months of abundant rainfall. Over-all mean gain for the experiment was $.60 \mathrm{~kg} /$ day. 
TABLE 1.-Growth responses of heifers on four treatments at Corozal Substation during 270 days

\begin{tabular}{|c|c|c|c|c|}
\hline \multirow{2}{*}{ Item } & \multicolumn{4}{|c|}{ Treatments } \\
\hline & 1 & 2 & 3 & 4 \\
\hline Stocking rate in pasture (head/ha) & 3.125 & 3.125 & 5.0 & 5.0 \\
\hline Annual fertilization (t/ha) & 2.25 & 1.65 & 2.25 & 2.25 \\
\hline Type of concentrate feed & none & bulky & standard & standard \\
\hline Daily concentrate allowance $(\mathrm{kg})$ & 一 & 3.0 & 1.8 & 4.0 \\
\hline Period of concentrate feeding & - & 3 mo. pregnant onward & throughout experiment & 5 mo. pregnant onward \\
\hline Initial age (mo) & 20.5 & 20.1 & 20.9 & 20.1 \\
\hline Initial liveweight $(\mathrm{kg})$ & $347.2 \pm 3.8$ & $347.3 \pm 3.9$ & $347.1 \pm 3.7$ & $346.8 \pm 3.9$ \\
\hline Final liveweight $(\mathrm{kg})$ & $517.3 \pm 8.0$ & $502.8 \pm 9.6$ & $511.7 \pm 7.1$ & $502.3 \pm 8.3$ \\
\hline Daily gain in liveweight $(\mathrm{kg})$ & $.63 \pm .02$ & $.57 \pm .02$ & $.61 \pm .02$ & $.58 \pm .02$ \\
\hline Final height at withers $(\mathrm{cm})$ & $134.4 \pm .7$ & $135.3 \pm .9$ & $135.0 \pm .6$ & $135.3 \pm .6$ \\
\hline Final body length $(\mathrm{cm})$ & $138.8 \pm .7$ & $138.2 \pm .9$ & $138.2 \pm .5$ & $136.9 \pm .6$ \\
\hline Final heart girth $(\mathrm{cm})$ & $189.3 \pm .9$ & $188.0 \pm 1.4$ & $189.1 \pm 1.3$ & $187.1 \pm 1.3$ \\
\hline Days pregnant at termination & 223 & 199 & 215 & 219 \\
\hline \multirow[t]{2}{*}{ Total intake of concentrates $(\mathrm{kg})$} & 0 & 339 & 486 & 275 \\
\hline & \multicolumn{4}{|c|}{ Post experimental observations at owners' farms } \\
\hline \multicolumn{5}{|l|}{ Liveweight of dams after calving } \\
\hline number observed. & 12 & 13 & 14 & 13 \\
\hline mean $\pm \mathrm{SE}(\mathrm{kg})$ & $485.4 \pm 13.6$ & $506.0 \pm 15.1$ & $492.7 \pm 13.0$ & $505.7 \pm 10.2$ \\
\hline \multicolumn{5}{|l|}{ Liveweight of calves at birth } \\
\hline number observed & 11 & 12 & 11 & 12 \\
\hline mean $\pm \mathrm{SE}(\mathrm{kg})$ & $43.3 \pm 1.7$ & $44.9 \pm 1.6$ & $42.2 \pm 1.8$ & $44.8 \pm 1.5$ \\
\hline
\end{tabular}


The method of allocating heifers to groups resulted in nearly identical mean initial liveweights per treatment $(347 \mathrm{~kg})$ and within-group variabilities (table 1). After 270 days of experimentation, group means ranged from $502 \mathrm{~kg}$ (treatment 4) to $517 \mathrm{~kg}$ (treatment 1), representing relative increases of $45 \%$ to $49 \%$, respectively. Final within-group variabilities were more than double initial values, but with no discernible difference between the control and other treatments in this regard (table 1).

Mean initial heart girth was $162.3 \mathrm{~cm}$ over-all, with none of the group means deviating by more than $0.3 \mathrm{~cm}$. At conclusion of each of the first three successive periods the general mean stood at 167.2, 169.4, and 171.6 $\mathrm{cm}$; thereafter, it increased to $178.7 \mathrm{~cm}$ after period 6 , and $188.4 \mathrm{~cm}$ at termination of the experiment. Final group means (table 1) showed a maximal dispersal of $2.2 \mathrm{~cm}$, ranging from $187.1 \mathrm{~cm}$ (treatment 4) to $189.3 \mathrm{~cm}$ (treatment 1). Relative increases in this parameter during 270 days ranged from $15 \%$ to $17 \%$. Logically, final ranking of the four groups was the same in both heart girth and liveweight.

Height at withers averaged $125.8 \mathrm{~cm}$ initially over-all, and showed a gradual increase to $135.0 \mathrm{~cm}$ at completion of the experiment; relative increase was $7 \%$. On only one occasion did any group mean deviate from the general mean by $1 \mathrm{~cm}$ or more: a $1.1 \mathrm{~cm}$ inferiority of treatment 1 after period 6. By the end of the experiment this difference had narrowed to $0.6 \mathrm{~cm}$ (table 1). The observation that treatment 1 had the highest mean liveweight but the lowest wither height supports the conclusion, reached in previous studies (2), that this measurement is not an accurate predictor of liveweight.

Body length (withers to pinbones) was about equal to wither height in most cases. Initial group means of body length ranged from $123.4 \mathrm{~cm}$ (treatment 4) to $124.8 \mathrm{~cm}$ (treatment 1), both representing deviations of $.7 \mathrm{~cm}$ from the over-all mean; final means (table 1) ranged from 136.9 $\mathrm{cm}$ to $138.8 \mathrm{~cm}$, with the same two groups deviating maximally from the general mean by $1.1 \mathrm{~cm}$ and $0.8 \mathrm{~cm}$, respectively. Over-all relative increase was $11 \%$, from $124.1 \mathrm{~cm}$ to $138.0 \mathrm{~cm}$. Treatments had no significant ( $P$ $=.05$ ) effects on growth, in terms of liveweight or any of the body measurements.

Heifers of treatments 1, 3, and 4 were at nearly the same mean day of pregnancy (215 to 223) upon conclusion of the experiment (table 1); treatment-2 heifers were at an earlier mean stage (199 days). One animal of the treatment 2 group, believed to be pregnant when leaving Corozal, required rebreeding and finally calved nearly 10 months after completion of the experiment. In general, there was little evidence of treatment effects on the intervals required to achieve conception and parturition. Mean age at first calving was $31.2,32.2,31.7$, and 30.8 months in animals of the four respective treatments (table 2). 
TABLE 2.-First lactation performance at owners' farms of heifers formerly on four treatments at Corozal Substation

\begin{tabular}{|c|c|c|c|c|}
\hline \multirow{2}{*}{ Item } & \multicolumn{4}{|c|}{ Former treatments } \\
\hline & 1 & 2 & 3 & 4 \\
\hline Number of lactations & 15 & 14 & 15 & 15 \\
\hline Age at first calving (mo) & 31.2 & 32.2 & 31.7 & 30.8 \\
\hline \multicolumn{5}{|l|}{ Length of lactation } \\
\hline 305 days or more (no.) & 7 & 6 & 7 & 9 \\
\hline less than 305 days (rio.) & 8 & 8 & 8 & 6 \\
\hline mean, all lactations (days) ${ }^{1}$ & 241 & 264 & 257 & 288 \\
\hline mean, short lactations (days) & 184 & 233 & 215 & 263 \\
\hline \multicolumn{5}{|c|}{$\begin{array}{l}\text { DHIA milk yield, } 305 \text {-day, mature- } \\
\text { equivalent basis }\end{array}$} \\
\hline mean $(\mathrm{kg})$ & 4,210 & 4,253 & 4,762 & 4,683 \\
\hline standard error $(\mathrm{kg})$ & 444 & 468 & 370 & 187 \\
\hline coefficient of variation $(\%)$ & 40.8 & 41.1 & 30.1 & 15.4 \\
\hline \multicolumn{5}{|l|}{ DHIA milk fat content } \\
\hline mean $(\%)$ & 2.95 & 2.88 & 3.04 & 2.91 \\
\hline standard error $(\%)$ & .09 & .09 & .07 & .06 \\
\hline
\end{tabular}

${ }^{1}$ Excluding days of lactation beyond 305.

Liveweights immediately after calving were obtained from 52 of 59 returned heifers. Unfortunately, 3 missed observations were among control heifers; the remaining 12 of this group had a mean final live-weight at Corozal of $523 \mathrm{~kg}$ and a mean weight after calving of $485 \mathrm{~kg}$ (table 1). Corresponding values of heifers of the other groups, for which both weights were available, were as follows: treatment $2,507 \mathrm{~kg}$ and $506 \mathrm{~kg}$; treatment 3,510 $\mathrm{kg}$ and $493 \mathrm{~kg}$; treatment 4,502 kg and $506 \mathrm{~kg}$. Thus, control heifers, unsupplemented prior to calving at their owners' farms, weighed less after calving than the supplemented animals. No appreciable differences were noted among treatments in birth weights of calves born to experimental heifers (table 1), although missing observations were more numerous in this criterion. Incidence of stillborn calves was one in each of groups 1, 2, and 3; all calves born to group-4 heifers were live.

One animal of treatment 1 died 71 days after calving because of systemic infection resulting from foot rot. Another member of this group was culled for lameness and low production after 128 days of lactation. The other 57 returned heifers remained in their respective herds at least until completing one lactation. Seven of these first lactations lasted less than 180 days, including one (155 days) in group 1, another of equal duration in group 2, four (157, 157, 163, and 179 days) in group 3, and one (179 days) in group 4. Twenty-nine first lactations were of standard 305 day duration or longer. Group 4 had the highest proportion of fulllength lactations (9/15) and mean number of days lactating (288), excluding days beyond 305 (table 2). Group 1 had the lowest mean for 
the number of days lactating (241); groups 2 and 3 were intermediate (264 and 257, respectively). This same ranking of the four ex-treatment groups was obtained when only lactations shorter than 305 days were considered (table 2).

Thus, some evidence was found of a possible adverse effect of the control treatment on lactation length, although a much larger number of observations would be required to confirm such an effect. Furthermore, it should be noted that for many of these animals considerable time elapsed from the date of returning to their owners' farms until parturition. Mean number of days were $60,84,68$, and 64 in the four respective groups. The alimentation provided during this interval, especially with regard to pasture quality, could partially obscure the effects of treatments compared at Corozal.

Groups (including any effect of former treatment) did not differ significantly $(\mathrm{P}=.05)$ in milk production parameters during first lactation. Daily production during the peak month averaged $18.9 \pm .7 \mathrm{~kg}$ over-all and $18.4,18.4,18.5$, and $20.2 \mathrm{~kg}$ in the four respective groups. DHIA lactation yields, extended to 305 days where applicable and adjusted to a mature-equivalent basis, showed a general mean of 4,481 $\pm 188 \mathrm{~kg}$. Group means ranged from 4,210 $\mathrm{kg}$ to $4,762 \mathrm{~kg}$ for treatments 1 and 3 , respectively (table 2). Uniformity of lactation yield was greatest in group 4 (standard errors and coefficients of variation in table 2).

The effect of farms on first lactation yield was significant $(P=.01)$. Numbers of returned animals from the four respective groups and (total number) at each farm and mean milk production per farm of the experimental animals were as follows: Santa Elena, 4, 4, 3, 1 (12) 5,702 kg; Cidra, 4, 2, 3, 2 (11) 5,108 kg; Candelaria, 1, 1, 4, 3 (9) 4,518 kg; Fortuna, $6,7,5,9(27) 3,670 \mathrm{~kg}$. The poor average at Fortuna was due in part to sporadic difficulty with the milk metering device, which tended to underestimate true production during several months of this study. Unfortunately, no reliable correction was possible for this bias, thus the data were left as recorded. These errors, being random, should not seriously affect the group comparisons, which is the matter of primary interest. Treatments 4 and 2 may have been slightly penalized in relation to the other groups because of a higher proportion of animals at this farm. The problem in question had a greater relative effect on lactation yield than on yield during the peak month; Fortuna Farm was $18.2 \%$ below the general mean in the former parameter, but only $10.8 \%$ below in the latter. No significant $(\mathrm{P}=.05)$ group $\times$ farm interaction was found. Mean first lactation milk fat percentage was 2.94 over-all, with none of the group means deviating by more than .10\% (table 2).

The present finding of no significant effect of prepartum concentrate feeding on first lactation milk production agrees with results from Aus- 
tralia (7), in which 17 pairs of monozygous twin heifers, reared on equal intakes of metabolizable energy from either hay alone or a 1:1 mixture of hay and concentrate, produced equally well during first lactation. After reviewing the world literature, Broster (3) concluded that concentrate feeding prior to calving had no special stimulatory effect on first lactation yield independent of general body condition.

A postpartum examination of the reproductive organs was recorded for 46 of the animals; those diagnosed normal, in proportion to the total number recorded, were as follows in the four respective groups: 8/10, 7/ $10,9 / 12$, and $11 / 14$. Interval from parturition to first observed estrus was recorded for only 28 animals. Although incomplete, these data indicate that group 1 heifers delayed longer in returning to heat postpartum (63 days) vs. a mean of 36 days in the remaining animals. This difference might have resulted from the greater loss of bodyweight of group 1 heifers from the time of leaving Corozal until after calving.

In calculating the number of artificial inseminations required to reestablish pregnancy postpartum, 4 animals of group 1 were excluded (2 mentioned previously, 1 culled after many unsuccessful inseminations, and 1 that died of bloat after completing a short lactation without being rebred); two were excluded from each of the other groups as follows: group 2, 1 animal bred more than 8 times (total not recorded) before conceiving and another culled for infertility after aborting; group 3, 1 individual bred 13 times and another more than 6 (total not recorded) before conceiving; group 4, 1 animal culled for low production without being rebred and another bred 9 times before conceiving. Of the remaining 49 heifers, those of group 2 required 1.67 inseminations per conception, whereas means for the other groups ranged from 2.73 to 2.77 .

The proportion of animals requiring medical attention in the attempt to achieve second pregnancy was highest in group $3(11 / 15)$ compared with 5 or 6 per group among the remaining population. Animals of groups 1 and 3 tended toward a higher incidence of non-reproductive health problems, especially lameness, while those of group 2 had the most trouble with mastitis ( 5 clinical cases). Liveweight upon drying off at the end of first lactation was recorded for less than half the animals. The limited data available tend to indicate that group 1 animals recovered from their lower weights after first calving and equaled the others in subsequent body size. Numbers of animals not remaining in their respective herds until second calving because of death or culling were $4,2,1$, and 1 in the four respective groups.

Forty-eight of these animals completed a second lactation, 10, 11, 14, and 13 from each of the respective former treatment groups. Corresponding means of DHIA 305-day, mature-equivalent milk production were $5,287,5,044,5,264$, and $5,350 \mathrm{~kg}$. The four farms ranked in the same 
order as previously, with means ranging from 5,779 $\mathrm{kg}$ for Santa Elena to $4,950 \mathrm{~kg}$ for Fortuna. However, analysis of variance revealed no significant $(\mathrm{P}=.05)$ effects of farms, treatments or farm $\times$ treatment interaction on second lactation yield. At a final census 3 years after returning these animals to their owners' farms, the survivors from the four respective groups numbered $7,11,10$, and 12 .

In conclusion, under the excellent grazing conditions that prevailed in this experiment, with an annual fertilization rate of $338 \mathrm{~kg}$ of nitrogen/ ha and a stocking rate of 3.125 animals/ha, the control treatment (without concentrates) was entirely satisfactory for promoting normal growth and first parturition of replacement dairy heifers. A lower fertilization rate (248 $\mathrm{kg} \mathrm{N} / \mathrm{ha}$ ) combined with bulky concentrates supplementation beginning at 3 months of gestation (treatment 2) produced slightly poorer growth than the control. The use of a higher stocking rate (5 animals/ha) at the same fertilization rate as that of the control and with more or less the same amount of concentrate supplementation in treatments 3 and 4 , respectively, was also shown to be satisfactory, but not superior to the control in promoting growth. Previous experiments led to similar conclusions $(2,5,6)$.

Therefore, if subsequent lactational performance and longevity are not taken into account, prepartum concentrate feeding would definitely not be recommended except possibly where desired to permit a higher stocking rate or a reduction in the amount of fertilizer employed. The present postpartum observations were too few to permit firm conclusions, but they lend initial support to the belief, held by some commercial dairymen, that heifers supplemented with concentrates prior to calving tend to suffer less attrition during first lactation (and possibly beyond) than those reared solely with herbage. It might be postulated that previous exposure to concentrates facilitates postpartum adjustment to rations involving heavy concentrate feeding. Additional studies are needed to further assess this important aspect of raising dairy heifers.

\section{RESUMEN}

Sesenta novillas Holstein, prestadas por fincas privadas, se estratificaron en 15 cuartetos, a base de peso vivo, al alcanzar la edad de aparearse y se incluyeron en un experimento diseñado en bloques al azar, con cuatro tratamientos basados en apacentamiento con suplementación o sin ella hasta poco antes del parto. Los tratamientos fueron como sigue: (1) densidad de apacentamiento 3.125 cabezas por ha, pastos abonados con 2.25 Tm/ha de un análisis 15-5-10 anualmente, sin suplementos; (2) la misma densidad, $1.65 \mathrm{Tm}$ de abono, suplemento de $3 \mathrm{~kg}$ por cabeza diariamente de un alimento concentrado voluminoso a partir de los 3 meses de preñez; (3) 5 cabezas/ha, abonamiento como en el tratamiento 
1, suplementación de $1.8 \mathrm{~kg}$ diarios de alimento concentrado durante todo el experimento; (4) igual al tratamiento 3 , excepto con suplementación a razón de $4 \mathrm{~kg}$ diarios a partir del quinto mes de preñez.

Durante 270 dias, los pesos vivos subieron de $347 \mathrm{~kg}$ inicialmente a medios entre 502 y $517 \mathrm{~kg}$ en los tratamientos 4 y 1 , respectivamente. Las ganancias diarias de $.63, .57, .61$ y $.58 \mathrm{~kg}$ en los cuatro respectivos tratamientos no mostraron diferencias significativas. Los tratamientos tuvieron muy poco efecto sobre el crecimiento en la altura a la cruz, la circunferencia torácica y la longitud del cuerpo. La edad media al primer parto, después del regreso a las fincas de origen, varió entre 30.8 y 32.2 meses en los tratamientos 4 y 2 , respectivamente. Los rendimientos medios de leche durante la primera lactancia, según los registros DHIA (Asociación para el Mejoramiento de Hatos Lecheros) ajustados a 305 dias y a equivalencia de madurez, fueron $4,210,4,253,4,762$ y $4,683 \mathrm{~kg}$ en los animales previamente asignados a los cuatro respectivos tratamientos, no habiendo diferencias significativas entre éstos.

En condiciones excelentes de apacentamiento, tal como las hubo en este experimento, no se demostró que el uso de alimento concentrado antes del parto fuera necesario para lograr crecimiento corporal, reproducción y producción lechera normales, aunque dicha práctica resultó en una menor incidencia posparto de bajas, debidas a mortalidad o eliminación del hato por diversos problemas, que la alimentación de novillas a base de pasto únicamente.

\section{LITERATURE CITED}

1. Annon., 1976. Conclusiones y recomendaciones de las investigaciones, Esta. Exp. Pastos y Forrajes Indio Hatuey, Matanzas, Cuba.

2. Bravo-Ramos, L., 1981. Evaluación de sistemas de alimentación para la crianza de novillas de reemplazo, M.S. Thesis. Mayagüez Campus, Univ. P.R.

3. Broster, W. H., 1971. The effect of milk yield of the cow of the level of feeding before calving, Dairy Sci. Abstr. 33: 253-70.

4. Carlo, I. and Vélez, J., 1978. Evaluation of different feeding systems for dairy heifers, J. Agric. Univ. P.R. 62: 311-20.

5. Caro-Costas, R. and Vicente-Chandler, J., 1979. Effect of supplementary feeding of concentrates and of restricted grazing on Holstein heifers on intensively managed grass pasture, J. Agric. Univ. P.R. 63: 336-43.

6. Mendoza, R., 1977. Comparación de tres sistemas de alimentación en la crianza de novillas para reemplazo, Esta. Exp. Agric. Univ. P.R. Publ. 115.

7. Rogers, G. L., Robinson, I. B., Chandler, N. J. and Day, I., 1981. Milk production by grazing cows given different types of diet in late pregnancy, Aust. J. Exp. Agric. Anim. Husb. 21: 163-66. From Dairy Sci. Abstr. 44: 86, No. 747. 1982.

8. Soldevila, M., Green, J. J., Sotomayor, A., Arroyo, J. A. y Vélez, J., 1979. Alimentación de novillas Holstein a base exclusiva de pastos táner, pangolas común y milangiana, guinea y signal cultivados durante las cuatro estaciones del año, Esta Exp. Agric. Univ. P.R. Publ. 127. 